\title{
Parliaments as Peacebuilders
}

\section{BY RASHEED DRAMAN}

STATES THAT ARE EXPERIENCING or coming out of conflict are embroiled in fragility for two main reasons: first, because of the breakdown of civil mechanisms of dialogue; and second, because they are unable to manage the disputes with groups of citizens who voice their grievances. Democracy is central to conflict management. The democratic peace thesis, widely accepted among international relations theorists, posits that democracies rarely go to war with other democracies and, by extension, have non-violent methods of resolving internal disputes. Today, democracy is synonymous with peaceful conflict management.

Conflicts occur in all societies but when managed peacefully, they can sometimes spark positive social and economic reforms. Societies are confronted daily with conflicts of all kinds, but only those societies that subscribe to the democratic ethos are able to manage conflictual situations within their borders and resolve them peacefully.

Fragile states share this predicament: 1) either the government, by its repressive nature, does not create the space for negotiation/dialogue; or 2) it completely stifles dissent in a violent way. People with grievances are thus left with only one option to make their case: the use of force. In such states, parliaments provide an important venue where differences are resolved. In fact, in such situations, parliaments are able to substitute the resort to physical violence with dialogue, and the rule of force with the rule of law. Thus, in the nascent democracies of the developing world, which are fragile, the role of parliaments in the national security dialogue is critical, as these countries wade through the messy period of consolidating democratic governance.

But despite the critical role parliament could play in ensuring peace, in most peace negotiations and subsequent peacebuilding efforts, parliament is ignored. This is further complicated by the fact that most donors are often unwilling to support democratic development in fragile states. The main argument they advance is one of insecurity and lack of democratic structures. They forget that in those societies, everything must be done from scratch. Institutions have to be reconstituted and trust has to be rebuilt and, above all, people have to start life all over again.

In our work at the Parliamentary Centre (PC), we continue to see an important causal link between the role of parliament and peacebuilding efforts. In some of the fragile states where the PG works-Sierra Leone, Liberia, Rwanda, Ethiopia,
- Cambodia and Sudan-through the platform for dialogue created by their democratic processes, parliaments are playing a vital role in conflict prevention, resolution and management. They are serving as venues where groups that have been fighting each other in the past now sit at the table and attempt to resolve their differences with words instead of bullets.

But these countries are experiencing difficult transitions to democracy, where their parliaments are weak, poor, misinformed, with low capacities, and understaffed. In fact, some of those parliaments lack the most rudimentary infrastructure of a democratic institution-they do not have proper meeting places, or offices for the MPs; or even the facilities to make tea and coffee.

This situation is exacerbated by one common trend: the Executive dominates the management of state affairs. In most fragile states, the Executive hides behind the cloak of "peacebuilding" to pursue policies that are dictatorial. These policies tend to take the country back to instability.

The heavy hand of the Executive can be neutralized if parliament is strong and effective. Therefore, supporting parliaments in fragile states is a peacebuilding imperative. One of the key priorities in fragile states is the need to get the security sector under firm civilian control, and it takes a strong and well-functioning parliament to accomplish this crucial task. Parliament also provides an avenue to healing and reconciliation. Most importantly, parliament, when properly constituted and representative of the people, gives a stake to all citizens in the democratic process, and ultimately helps to consolidate peace.

To sum up, democracy is perhaps the best vehicle for establishing stability in fragile states. A leading advocate of democracy once remarked:

democracies must vigorously mobilize their legitimate instruments of law enforcement to counter this growing threat to their security. But a more fundamental and enduring assault on international terrorism requires political change to bring down zealous, paranoiac dictatorships and to allow aggrieved groups in all countries to pursue their interests through open, peaceful, and constitutional means.

And there is no better way for citizens to pursue their interests than through their representative institution-the parliament.

Rasheed Draman is Director, Africa Programs, Parliamentary Centre, Ghana. 